\title{
Towards Regional Scale Stormwater Flood Management Strategies through Rapid Preliminary Intervention Screening
}

\author{
James L. Webber ${ }^{1, *(\mathbb{D}}$, Mariano Balbi ${ }^{2}{ }^{(}$, David Lallemant ${ }^{3,4}{ }^{1}$, Michael J. Gibson ${ }^{1}$, Guangtao Fu ${ }^{1}$, \\ David Butler ${ }^{1}$ and Perrine Hamel ${ }^{3,4,5}$
}

1 Centre for Water Systems, University of Exeter, Exeter EX4 4QF, UK; M.J.Gibson@exeter.ac.uk (M.J.G.); G.Fu@exeter.ac.uk (G.F.); D.Butler@exeter.ac.uk (D.B.)

2 Laboratorio de Dinámica de Estructuras, Universidad de Buenos Aires, Buenos Aires C1053, Argentina; mabalbi@fi.uba.ar

3 Asian School of the Environment, Nanyang Technological University, Singapore 637459, Singapore; dlallemant@ntu.edu.sg (D.L.); perrine.hamel@ntu.edu.sg (P.H.)

4 Earth Observatory of Singapore, Nanyang Technological University, Singapore 637459, Singapore

5 Natural Capital Project, Stanford Woods Institute on the Environment, Stanford University, Stanford, CA 94305, USA

* Correspondence: J.Webber2@exeter.ac.uk

check for updates

Citation: Webber, J.L.; Balbi, M.; Lallemant, D.; Gibson, M.J.; Fu, G.; Butler, D.; Hamel, P. Towards Regional Scale Stormwater Flood Management Strategies through Rapid Preliminary Intervention Screening. Water 2021, 13, 2027. https:/ / doi.org/10.3390/w13152027

Academic Editors: Mingfu Guan and Sangaralingam Ahilan

Received: 14 June 2021

Accepted: 21 July 2021

Published: 24 July 2021

Publisher's Note: MDPI stays neutral with regard to jurisdictional claims in published maps and institutional affiliations.

Copyright: (c) 2021 by the authors. Licensee MDPI, Basel, Switzerland. This article is an open access article distributed under the terms and conditions of the Creative Commons Attribution (CC BY) license (https:// creativecommons.org/licenses/by/ $4.0 /)$.

\begin{abstract}
This paper presents the advantages and opportunities for rapid preliminary intervention screening to enhance inclusion of green infrastructures in regional scale stormwater management. Stormwater flooding is widely recognised as a significant and worsening natural hazard across the globe; however, current management approaches aimed at the site scale do not adequately explore opportunities for integrated management at the regional scale at which decisions are made. This research addresses this gap through supporting the development of stormwater management strategies, including green infrastructure, at a regional scale. This is achieved through upscaling a modelling approach using a spatially explicit inundation model (CADDIES) coupled with an economic model of inundation loss (OpenProFIA) to support widescale evaluation of green infrastructure during the informative early-stage development of stormwater management strategies. This novel regional scale approach is demonstrated across a case study of the San Francisco Bay Area, spanning 8300 sq $\mathrm{km}$. The main opportunity from this regional approach is to identify spatial and temporal trends which are used to inform regional planning and direct future detailed modelling efforts. The study highlights several limitations of the new method, suggesting it should be applied as part of a suite of landscape management approaches; however, highlights that it has the potential to complement existing stormwater management toolkits.
\end{abstract}

Keywords: flood modelling; green infrastructure; regional planning; stormwater management

\section{Introduction}

Cities are facing unprecedented shocks from natural hazards, such as floods, droughts and heat-waves [1-5]. The convergence of people, economic activity and social function makes cities uniquely vulnerable to the challenges of a changing climate, growing population and urban expansion [6,7]. Managing environmental hazards is necessary and urgent to prevent major future disruption to social and economic functions in cities [8], but assessing and implementing management strategies at the regional scale is complicated and expensive, particularly in the case of managing large conurbations. New approaches and methodologies are required for the effective future management of urban environments and mitigation of natural hazards [9]. In particular, recent studies emphasise a need to manage stormwater flood hazards [1,2,10-12].

Stormwater flooding is a global issue, with many international government reports and academic studies emphasising the need for management strategies to be implemented $[5,10,12,13]$. Need for action is evidenced through growth of international surface 
and storm water management agendas such as sustainable drainage systems (SuDS) [14], sponge cities [15], water sensitive urban design (WSUD) [5] and low impact development (LID) [16], to name a few [17].

It has long been understood that climate change, population growth and urban expansion are increasing future stormwater risks to cities [7]. However, recent advances in research highlight that the magnitude of these hazards has been systematically underestimated [12]. Even in low impact climate change scenarios, cities are likely to face far greater hazards from flooding than previously recognised [2]. A changing climate is predicted to increase the seasonality and variability of weather patterns, influencing the occurrence and characteristics of extreme weather events $[1,7,18]$. The most relevant impact to stormwater management is the increase in intensity and duration of extreme precipitation which may result in surface water flooding as a result of exceeding the capacity of existing drainage systems [19]. Studies have highlighted that it is these extreme events, and not gradual change, which pose the most risk to humans [20]. This is of particular concern where climate changes could also exacerbate other anthropogenic pressures such as urban sprawl and changes in land use [21]. Therefore, it is crucial that future urban and landscape management accommodates mechanisms to plan for extreme events.

A promising approach for managing urban stormwater relies on green infrastructure; also referred to as natural infrastructure, blue-green systems, nature-based solutions and a variety of related concepts described in Fletcher et al. [17]. The terminology relating to green infrastructure, and synonymous concepts, is diverse and cross-disciplinary. Terminology is also differentiated geographically, with different terminologies preferred in different regions. For example, but not limited to, SuDS (UK), WSUD (Australia), LID (USA) and sponge cities (China) [17]. For this study we use the terms 'green infrastructure' and 'urban greening' to represent nature based, decentralised and above ground stormwater management practices, such as rain gardens, green roofs and permeable paving, among many other measures [17,22-24]. We have applied these terms within our paper as they are increasingly common within the international stormwater vernacular and capture the essence of many other significant synonymous terminologies [17,25]. In addition to this, the term is accessible to multidisciplinary stakeholders involved in the regional planning process and reflects the multiple ecosystem services which green stormwater infrastructure can develop, such as benefits to air quality, recreation, biodiversity and water provision, to name a few [15,26-29].

Research indicates that green infrastructure is particularly promising when distributed at a catchment scale [30-32]. Recent interest in green infrastructure stems from the recognition that they can provide a range of services, for example, heat mitigation or flood risk mitigation, and that proper management of these assets can help enhance services across landscapes. However, despite a wealth of models and approaches designed to evaluate ecosystem services, many current approaches do not adequately represent stormwater runoff mitigation within these frameworks.

Ecosystem services models for stormwater runoff mitigation are often simplistic, focusing on runoff reduction at a site or small catchment scale, but failing to examine the actual benefits at a coordinated regional scale $[16,22,33,34]$ : in the case of flood risk mitigation, for example, they rarely estimate where and how much inundation may be reduced due to investment in green infrastructure [30]. Yet, to understand where green infrastructure has the highest benefits, this spatial understanding is necessary [35], highlighting the need for spatially-explicit but parsimonious stormwater ecosystem services models.

Several review articles specifically focus on assessing the tools available to quantitatively assess green infrastructure interventions. Elliott and Trowsdale [36] conducted a review of a broad spectrum of urban stormwater models specialised to include green infrastructure techniques. The authors identified 40 models and found the majority of models were not well suited to modelling high spatial resolution of individual interventions or their effects on catchment scale surface flood dynamics. Jayasooriya and $\mathrm{Ng}$ [37] conducted an updated review of current stormwater flood models by advancing the scope 
to assess incorporating economic analysis within models. The study identified several key challenges in developing green infrastructure modelling, in particular finding that research gaps exist regarding inclusion of a wider range of green infrastructure practices, applicability to a range of regions using easily obtainable input data, engaging stakeholders and using new technologies to advance capabilities of decision support systems. This finding is supported by recent analysis from the urban stormwater planning community, where it is highlighted that achieving flood management at local, regional and national levels requires significant developments in urban planning [26,34,38-40]. In particular, research calls for a need to address an 'implementation gap' in applying green infrastructure, where, although appropriate technical understanding for designing interventions is well-understood, a lack of early and effective multi-disciplinary integration, planning and evidence of success at a landscape scale has held back regional stormwater policies.

Another limitation of current regional scale modelling is that many frameworks assume an 'instrumental' use of information, requiring a high-level of confidence to inform site-specific decisions [41]. This includes, for example cost benefit analyses of interventions [42]; however, many applications, particularly those at the outset of regional management, only require the understanding of general trends to orient policies, support collaborations or inform next steps, such as prioritising areas to direct more resource intensive detailed modelling or identifying and connecting stakeholders $[5,26,38]$. This use of modelling information, referred to as 'strategic' [41,43], is particularly useful for integrated regional planning, where flood risk is coupled with other ecosystem services or socio-economic data $[16,38-40,44]$. Consequently, this research explores the application of a rapid and straightforward approach for initial stage decision support, with a key focus on developing a method applicable with easily accessible open data and capable of facilitating scenario exploration and collaborating diverse multi-disciplinary stakeholder engagement at the informative and influential preliminary stage of flood management.

This study responds to these challenges through exploring the benefits and limitations of applying a rapid screening tool to investigate, evidence and engage the potential of green infrastructure at a regional scale when developing stormwater management strategies. This is presented relative to a case study in San Francisco Bay, USA. The paper presents a method for rapid screening, illustrates the relevance of spatial information for regional landscape management, and presents specific findings regarding potential regional stormwater management in the San Francisco Bay Area.

\section{Materials and Methods}

This section describes the rapid assessment tools applied to represent and evaluate regional landscape management and introduces an example case study where these are applied to San Francisco Bay Area in the US.

\subsection{Rapid Flood Modelling Using Cellular Automata}

A rise in availability of high-resolution data has encouraged the development of a new series of models that apply novel cellular automata for modelling stormwater flooding. Cellular automata are grid-based systems that apply water routing rules based on simplified hydraulic equations to achieve speed increases versus traditional 2D models. The simplicity of this model structure is suited to computational parallelisation, providing the possibility of further speed increases [45].

A range of cellular automata flood models have been developed. Caviedes-Voullième et al. [46] carried out a review of current cellular automata flood models, identifying the relatively new development of the methodology, with the majority of advances made in the past 10 years. Early examples of these models were applied to simulate fluvial dynamics [47]. The approach has been applied to stormwater flood dynamics across flood plains [48-52]. Recent approaches have refined this application towards detailed simulation of urban environments, although so far this has been undertaken at limited scale [25,53-55]. 
This study applies the 'CADDIES' flood model (www.cafloodpro.com (accessed on 22 July 2021)) to develop a representation of the study region. CADDIES applies a cellular automata flood model to simulate overland flow across a 2D domain structured using a regular grid. Movement of runoff across the domain is calculated through a set of cell transition rules that calculate water movement between adjacent cells to specify changes in water level. Water level is calculated through adding an 'input' volume and subtracting an 'output' volume from water levels in each cell. The direction of runoff is then determined by ranking water levels between adjacent cells and smoothing out the water surface. The rate at which water is distributed between cells is a function of the cell roughness parameter. Full details, equations and validation of the CADDIES flood model are available across a range of previous studies [54-59]. Figure 1 presents a simplified version of this model architecture.

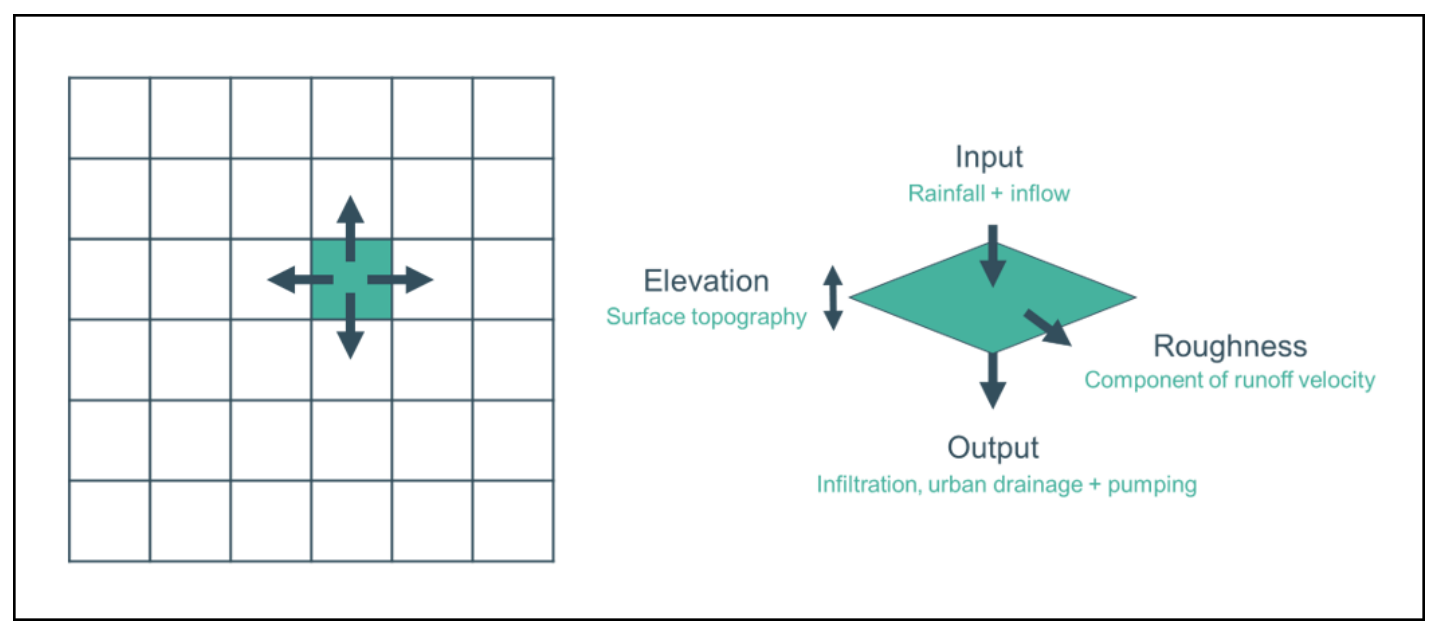

Figure 1. CADDIES modelling architecture. Runoff is produced from each cell based on input rate and is routed between neighbouring cells depending on its output, elevation and roughness parameters.

A key requirement in rapid modelling is the ability to efficiently set up and evaluate preliminary models to steer and enhance understanding. As such, the model is setup using efficient simplification of parameters to facilitate a streamlined analytical tool, suitable for early-stage option development.

Parameters are adapted on a cell-by-cell basis to alter the rate and quantity of runoff. These are cell elevation, roughness, input and output. Elevation (in $\mathrm{m}$ ) represents topography and is specified using a Digital Elevation Model (DEM). Roughness (in Manning's $\mathrm{n}$ coefficient) represents surface roughness and is used to calculate runoff speed through adapting the model time step. This value remains constant throughout a simulation. Input (in $\mathrm{mm} /$ hour) represents incoming water at each time step, typically through rainfall, although other inputs can also be included. This value is also time variable so that rainfall hyetographs can be included within the model. Output (in $\mathrm{mm} /$ hour) represents the rate of water removed from each cell at each time step. This value encapsulates the sum of infiltration, drainage, evapotranspiration and pumping. The value of potential maximum output remains consistent throughout the simulation. Manipulation of these four simple parameters is used to represent a wide range of potential surfaces and interventions $[25,60]$.

This approach affords simulation speed, but at a trade-off versus detailed representation of the urban environment. Previous research has highlighted the utility of this approach for conceptual and strategic modelling, but cautions against relying on this level of screening to imply detailed high resolution flood dynamics [58]. In particular, the method includes simplifications of the urban drainage system through cell output parametrisation. This approach is acceptable in terms of urban flooding during extreme stormwater runoff, where an over capacity drainage network is unable to contain flows and so overland runoff becomes the predominant flood route but should not be applied to 
simulate sewer flows during routine events which require a much more detailed breakdown of pipe flow, achievable using a coupled 1D network simulation. As the aim of this study is preliminary analysis and facilitating scenario exploration, it is deemed acceptable to use this high-level approach in this case.

\subsection{San Francisco Bay Area Case Study}

The San Francisco Bay Area is a large conurbation located in Northern California, United States. The area includes the nine counties surrounding the Bay: Alameda, Contra Costa, Marin, Napa, San Mateo, Santa Clara, Solano, Sonoma and San Francisco. The 2010 United States census approximates the population of the area as 7.15 million [61]. The study area investigated in this paper is the 8342 square $\mathrm{km}$ region representing the watersheds within the Bay Area (Figure 2). This area is represented using an open-source digital elevation model and land use classification. The DEM applies a $30 \mathrm{~m}$ by $30 \mathrm{~m}$ cell resolution representing broad elevation changes across a regional scale [62]. Land use is sampled at the same $30 \mathrm{~m}$ by $30 \mathrm{~m}$ resolution applied using the DEM and split into 25 possible classes [63], with 20 being present across the watershed study area (Figure 2). The water balance associated with each land use class modelled through adjusting the input, output and roughness parameters (Figure 1).

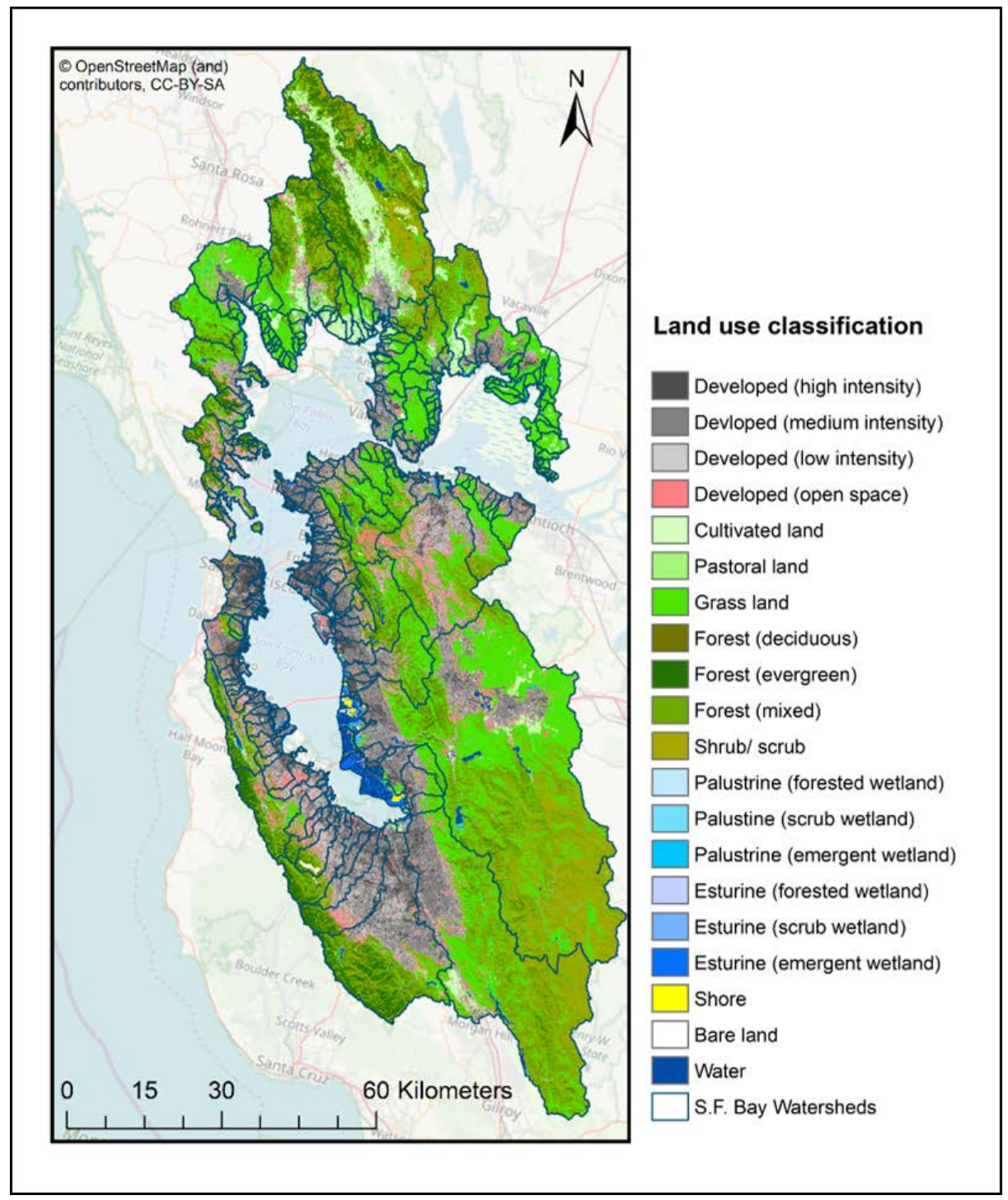

Figure 2. Land use classification across the San Francisco Bay Study Area. 
Model input parameters are used to specify the temporally and spatially variable rainfall intensity applied to the model surface (Figure 1). Rainfall intensities have been specified using the NOAA 'Atlas 14' point precipitation estimates for San Francisco [64]. Atlas 14 provides the intensity-duration-frequency (IDF) relationship applicable to the region. This IDF was constructed into design storms to represent a range of different rainfall events. The critical design rainfall associated with this region was found to be the two-hour rainfall event, therefore a rainfall distribution was created through mapping this event onto the six-hour rainfall characterised by NOAA.

Roughness parameters were specified using Manning's roughness coefficients for flood plains in the United States Geological Survey Scientific Investigations Report $[65,66]$. This report provides estimated value ranges for coefficients based on land use types, form and vegetation density, based on modified parameters linked to land use types from literature [67-69].

Output rates represent the water losses caused by infiltration through soils and drainage through surface and sub-surface infrastructure. Infiltration was defined based on the SWMM soil categories. Soils across the San Francisco Bay region are generally classified into Hydrological Soil Group C [70]. Group C soils have limited infiltration rates, leading to a moderately high runoff potential when wetted. The mid-range value for this group $(2.6 \mathrm{~mm} / \mathrm{h})$ is applied to non-urban land uses across the Bay scale model. It was assumed that palustrine and estuarine environments will likely already be saturated, therefore an infiltration rate of $0 \mathrm{~mm} /$ hour has been defined.

Output rates describing the urban drainage system across urban land use are difficult to characterise due to a wide range of drainage network capacities. For this study, the assumption of $15 \mathrm{~mm} /$ hour has been applied across all urban cells, representing the average intensity of a 10-year, 2-hour design storm event, suggested to be indicative of broad scale design standards for stormwater drainage. This assumption is in line with similar broad scale modelling applied across the UK Environment Agencies 'Risk of Flooding from Surface Water' methodology [71].

\subsection{Developing Intervention Scenarios for the Bay Area}

Intervention scenarios were developed to explore the role of a regional-scale flood risk assessment and the potential for stormwater management strategies at that scale. The study also aims to respond to a gap in knowledge regarding application of distributed green infrastructure. In response to this, a range of scenarios were evaluated, including a baseline for relative comparison, distributed rainwater capture and intensive urban greening through landscape management. Scenarios were implemented through developing characteristics of the intervention across each cell and then representing these through adjusting cell parameters.

The baseline scenario represented the study area with land uses as described in the previous section. The baseline was evaluated across 10, 25, 50, 100, 200 and 1000-year return period design storms.

The rainwater capture intervention represented implementation of tanks collecting runoff from roofs [72]. This was modelled through reducing the effective rainfall in each cell through manipulating the cell input parameter indicative of this input being captured before it reaches the cell surface [73]. The study included two variants of this scenario: moderate capture volume of 100001 of storage in each cell and an intensive scenario with $20,000 \mathrm{~L}$ of storage in each cell. This equates to approximately two and four domestic rainwater harvesting tanks within each $30 \times 30 \mathrm{~m}$ cell, respectively. The assumption was applied uniformly across all urban cells in the model and as such represents an aspirational long-term future for the Bay Area.

The urban greening intervention scenario represents the implementation of green infrastructure to capture runoff and adapt land surfaces to slow and retain runoff. The intervention was modelled in moderate and intensive variants, represented through the same assumptions outlined for rainwater tanks, plus the altering the cell roughness in 
urban areas to represent slowing runoff with greened surfaces. Developed urban land was attributed a Manning's value of 0.030 and open urban land was attributed 0.050 . These values are indicative of low and high values for high grass [67-69].

Intervention scenarios were evaluated using 25-year and 100-year return period design storms, indicative of a design standard and an extreme event, respectively.

\subsection{Valuing the Flood Management Benefits of Interventions}

Flood management valuation was undertaken using the open-source probabilistic flood impact analysis software (OpenProFIA) [74]. This software monetises the flood mitigation value of interventions through calculating Direct Economic Losses (DEL) caused by each flood scenario and then generates a comparison in losses between a baseline and each intervention scenario. Reduced damages attributed to interventions are valued as a positive outcome of the flood management scenario.

DEL are losses associated to the direct action of flooding on assets and people [75]. Other literature classifies this type of damage assessment as direct and tangible [76,77]. DEL can be further disaggregated into buildings, contents and inventory. 'Building' losses are the costs of damage to components that are permanently attached to the building (both structural and non-structural). 'Contents' losses are damages to elements inside the building that are not permanently attached to it. 'Inventory' losses are damages to stocks, and most relevant when examining impact to commerce and industry [78].

This study restricts calculation of DEL to 'Structural' and 'Contents' components, due to a need to provide an effective and high-level comparative metric, achievable using initial and exploratory modelling [79]. Indirect (i.e., cascading interruption of economic processes), intangible (i.e., health outcomes) and highly variable (i.e., stock) losses are not taken into account due to the complexity and lack of data to support such analysis at this high-level initial screening.

To analyse the impact of a particular hazard to the urban environment, the OpenProFIA tool combines three components to calculate DEL: hazard, exposure and vulnerability. Hazard refers to the likelihood and spatially distributed intensity of a potentially destructive phenomenon, here represented as a flood-depth map from CADDIES. Exposure refers to the location, attributes and value of assets potentially damaged. Vulnerability refers to the reaction of the assets when exposed to the forces produced by the hazard, for example a depth-damage function (also termed vulnerability curve). The flood-depth hazard map is transformed into a damage map through overlaying the exposure maps and corresponding vulnerability functions. DEL is then computed as the sum of damage times the total cost of each exposure object. Further details can be found in the documentation of the tool [74].

The hazard model used in the analysis is the CADDIES flood model, as described in previous sections of this paper. The maps of flood-depth peaks generated by this model are used as input in the OpenProFIA tool.

The exposure model, including the economic values of buildings, contents and inventories per occupancy type, was extracted from Hazard U.S. (HAZUS) software, developed by the U.S. Federal Emergency Management Agency (FEMA), which contains a United States wide database of General Building Stock characteristics aggregated at the censusblock-level [78].

The vulnerability model is represented by a deterministic depth-damage curve, relating the flood depth at a building site with the percentage of the total asset value that would be needed to replace/repair the building or its contents. Depth-damage curves are extracted from the FEMA and US Army Corps of Engineers (USACE) historic flood database using empirical data from past floods [80,81]. Total damage (DEL) is calculated through the sum of census block damages from each flood and intervention scenario. 


\section{Results}

\subsection{Evaluating Flood Depths Across a Range of Storm Return Periods}

To evaluate the change in flood extents resulting from increasing magnitude, Figure 3 presents peak flood depths during the 25, 100 and 1000-year return period events. Panels A-C show zoomed in flood depths across all return periods for four areas of interest. Panel D presents the full extent of the study area and spatial relationship of these four areas of interest. The relationship between each panel and the full spatial extent is shown through the same colour used for the borders of Panels A-C being used to indicate scale of cut outs in Panel D.
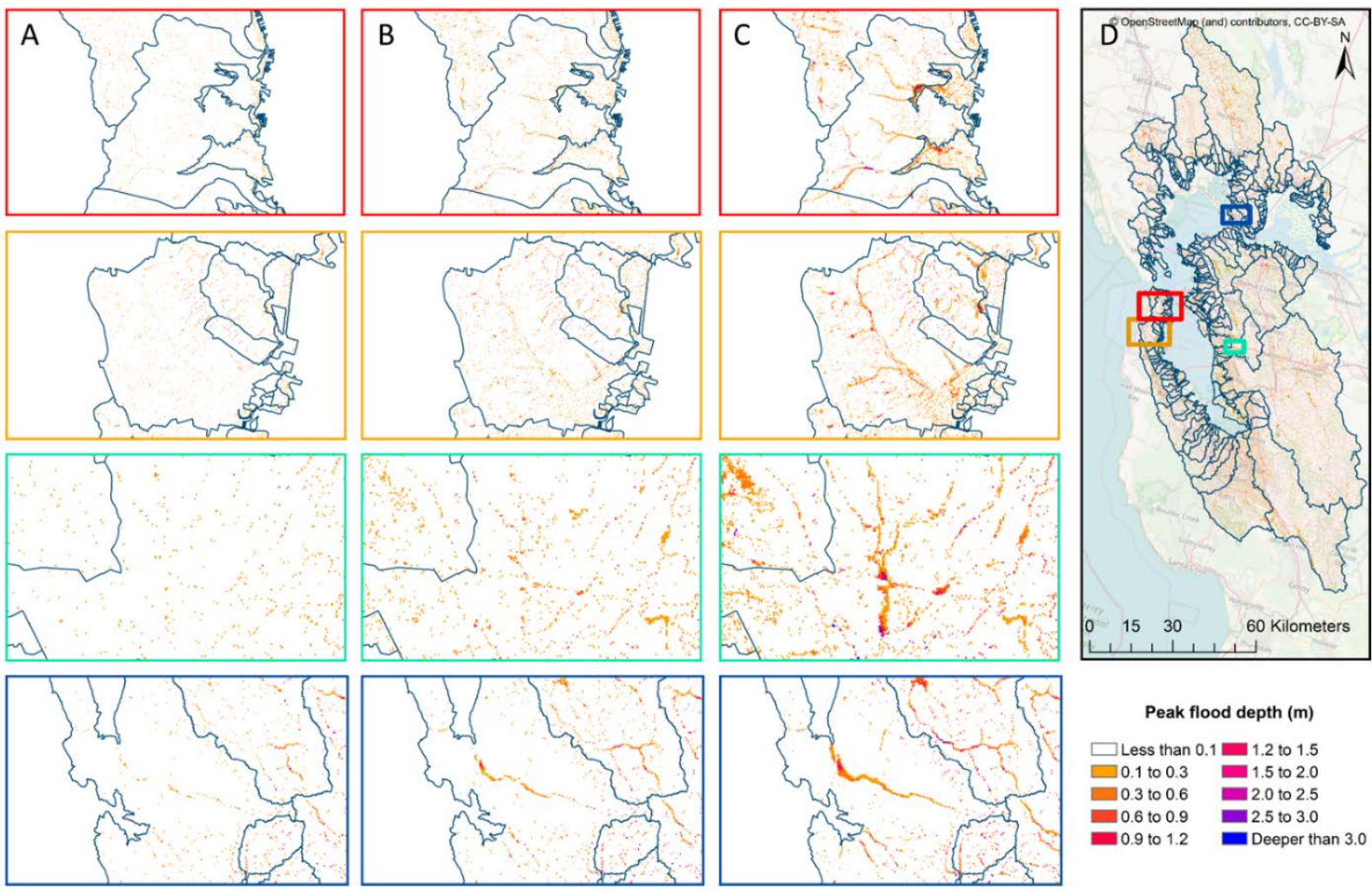

Figure 3. Peak flood depths with varying return periods during the two-hour event, with four highlighted watersheds in the: (A) 25-year; (B) 100-year; (C) 1000-year events; and (D) 1000-year across the entire Bay Area.

The model indicates depths of $0.3 \mathrm{~m}$ to $0.9 \mathrm{~m}$ in all highlighted catchments. As expected, flooding increases in line with the return period, with depths approaching $1.5 \mathrm{~m}$ to $2.0 \mathrm{~m}$ in the 100 and 1000-year return period events. Very high flood depths of up to $3.0 \mathrm{~m}$ are observed in localised regions during the 1000-year flood events, typically at the confluence of several flood routes intersecting in depressions in the DEM.

\subsection{Evaluating Flood Depths Across Scenarios}

Figure 4 presents peak flood depths predicted for the four interventions across the four highlighted areas during the 100-year return period, two-hour design storm. This indicates that the extent of deep flooding reduces as more intensive interventions are installed across the urban area. The best performing intervention in terms of achieving this flood reduction is the intensive urban greening through landscape management; however, even in this scenario deep flooding is still observed across the catchments. 

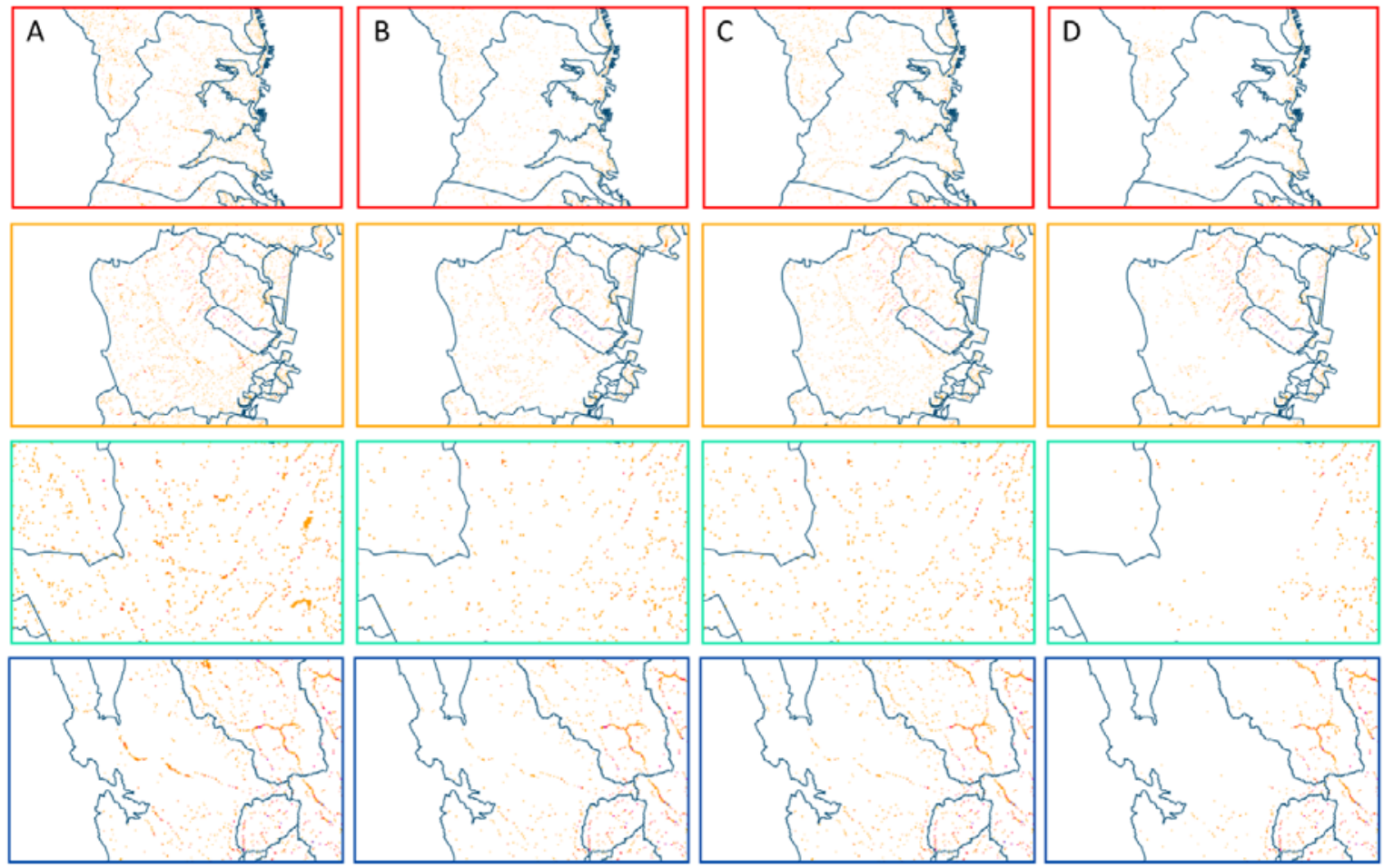

Column A: Moderate rainwater capture during the 100 year, 2 hour event Column B: Intensive rainwater capture during the 100 year, 2 hour event Column C: Moderate urban greening during the 100 year, 2 hour event Column D: Intensive urban greening during the 100 year, 2 hour event

Peak flood depth $(m)$

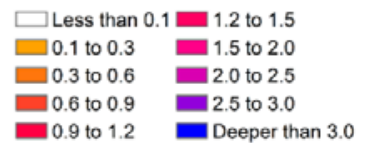

Figure 4. Comparing intervention effects on peak flood depth during 100-year return period, 2-h event. Reference scale regions set in Figure 3.

\subsection{Valuing the Flood Management Benefits of Interventions}

Actual impacts of regional scale flooding are challenging to observe over the largescale maps; therefore, the different interventions can be better compared through examining summary metrics which encapsulate the effect of strategies across the full study area. We have chosen to present our county level stormwater hazard evaluation for both return periods through the DEL metric. This is due to the potential for inundation extent to be potentially misleading when presented independently of context, as extent only captures the hazard coverage, irrespective of any spatial relationship of that coverage to hazard receptors. On the other hand, DEL captures both the inundation extent and likely damage, providing a metric encapsulating extent, depth and location into one impact value. This is of pertinence when considering a strategic regional scale assessment, such as ours, where large areas of stormwater flooding may be apparent, but are less significant to policy makers than understanding where flooding creates impacts. Table 1 presents DEL and ecosystem service valuation across in all scenarios through the 25 and 100-year return periods.

Table 1 indicates that the structural component of DEL is more than double the contents component of the calculation in all events, highlighting the importance of building fabric in determining damages and highlighting opportunities for advanced construction techniques to manage future losses. Flood resilient buildings are an emerging technology which may be able to reduce recovery time and minimise the structural damage mechanisms in future analysis [82,83].

All interventions provide flood management benefits across both the design standard and extreme return periods. However, the mitigated losses are similar when comparing the same intervention scenario for the 25 and the 100-year event, indicating that the intervention approaches a peak performance at which it is utilised at full capacity. 
Table 1. Direct Economic Losses and ecosystem valuation (millions USD). RWC = Rainwater capture.

\begin{tabular}{ccccc}
\hline Scenario & Structural & Contents & Total & $\begin{array}{c}\text { Losses } \\
\text { Mitigated }\end{array}$ \\
\hline Baseline 25 years & 903 & 361 & 1264 & - \\
Urban Greening Intensive 25 years & 312 & 120 & 432 & 832 \\
Urban Greening Moderate 25 years & 830 & 325 & 1155 & 109 \\
RWC Intensive 25 years & 357 & 140 & 497 & 767 \\
RWC Moderate 25 years & 766 & 304 & 1070 & 194 \\
Baseline 100 years & 1651 & 703 & 2354 & - \\
Urban Greening Intensive 100 years & 1157 & 460 & 1617 & 737 \\
Urban Greening Moderate 100 years & 1605 & 643 & 2248 & 106 \\
RWC Intensive 100 years & 1055 & 429 & 1483 & 871 \\
RWC Moderate 100 years & 1476 & 617 & 2093 & 261 \\
\hline
\end{tabular}

The intensive intervention application is the more effective measure in all scenarios. Doubling the storage size from 10,000 to 20,000 L per cell is shown to boost benefits by 732 and 573 million USD for urban greening and rainwater capture, respectively, in the 25-year return period event. This benefit is calculated to be 631 and 610 million USD for the 100-year return period storm.

Urban greening is the most effective intervention during the 25-year event, providing an estimated ecosystem service of 832 million USD; However, during the extreme 100-year return period event urban greening declines in effectiveness and rainwater capture becomes the most effective intervention, delivering an ecosystem service valued at 871 million USD. This is due to the slower runoff associated with urban greening leading to more ponding during very high intensity rainfall. In practice this could likely be mitigated through providing space for water to temporarily pond when designing urban greening interventions, such as parks, rain gardens and swales. This would ensure ponding is manageable, however it should be noted that there is always the potential for very intense storms to overwhelm storage capacities and so complementary flood resilience and recovery interventions should be considered alongside green infrastructure $[8,22,60]$. The change in intervention effectiveness ranking as the return period increases demonstrates the value of exploring a range of interventions and their responses to increasing return periods.

Despite large improvements attributed to interventions, significant damage costs remain across all scenarios, indicating that no strategy is able to entirely mitigate flood impacts independently.

The figures in Table 1 provide a synthesis of results, however, miss the spatial element observed in the flood maps. From these maps it can be seen that while the effective mitigation produced by the green infrastructure is widespread over the census blocks, there are many places where the baseline scenario actually yields less losses. This is due to an increment of very shallow inundation depths over a larger area due to ponding generated by the green infrastructure holding water in the upper catchment. However, this phenomenon of widespread ponding water does not appear in the less intense 25-year event, likely due to the intervention capacity managing a large amount of the rainfall. It is likely that this effect is a model artefact, since in practice due green infrastructure would be designed to ensure shallow water ponds away from properties.

Table 2 presents mitigated losses per county (absolute) and Table 3 presents this same value relative to the baseline. These tables highlight that benefits vary widely spatially across the case study, with a range of up to above 200 million from the highest to lowest benefiting county. As interventions are applied uniformly across all urban areas, this range is attributed to counties with a larger urban area receiving a larger benefit, however it also highlights the spatial effectiveness of interventions, which should be considered when evaluating large scale opportunities. 
Table 2. Spatial analysis of mitigated losses per county (millions USD). RWC = Rainwater capture.

\begin{tabular}{|c|c|c|c|c|c|c|c|c|}
\hline \multirow[t]{2}{*}{ County } & \multicolumn{2}{|c|}{$\begin{array}{l}\text { Urban Greening } \\
\text { (Intensive) }\end{array}$} & \multicolumn{2}{|c|}{$\begin{array}{c}\text { Urban Greening } \\
\text { (Moderate) }\end{array}$} & \multicolumn{2}{|c|}{$\begin{array}{c}\text { RWC } \\
\text { (Intensive) }\end{array}$} & \multicolumn{2}{|c|}{$\begin{array}{c}\text { RWC } \\
\text { (Moderate) }\end{array}$} \\
\hline & 25 Years & 100 Years & 25 Years & 100 Years & 25 Years & 100 Years & 25 Years & 100 Years \\
\hline Alameda & 207 & 196 & 30 & 30 & 186 & 224 & 47 & 69 \\
\hline $\begin{array}{l}\text { Contra } \\
\text { Costa }\end{array}$ & 119 & 99 & 12 & 19 & 117 & 124 & 29 & 37 \\
\hline Marin & 22 & 17 & 1 & -1 & 22 & 24 & 5 & 7 \\
\hline Napa & 19 & 14 & 3 & 4 & 18 & 16 & 5 & 5 \\
\hline $\begin{array}{c}\text { San } \\
\text { Francisco }\end{array}$ & 83 & 75 & 12 & 21 & 79 & 89 & 20 & 26 \\
\hline San Mateo & 83 & 72 & 10 & 9 & 79 & 87 & 20 & 25 \\
\hline Santa Clara & 237 & 224 & 32 & 27 & 208 & 253 & 53 & 78 \\
\hline Solano & 40 & 22 & 4 & -4 & 39 & 32 & 10 & 9 \\
\hline Sonoma & 18 & 18 & 1 & 2 & 17 & 22 & 4 & 6 \\
\hline
\end{tabular}

Table 3. Spatial analysis of mitigated losses per county relative to baseline (\%). RWC = Rainwater capture.

\begin{tabular}{|c|c|c|c|c|c|c|c|c|}
\hline \multirow[t]{2}{*}{ County } & \multicolumn{2}{|c|}{$\begin{array}{l}\text { Urban Greening } \\
\text { (Intensive) }\end{array}$} & \multicolumn{2}{|c|}{$\begin{array}{l}\text { Urban Greening } \\
\text { (Moderate) }\end{array}$} & \multicolumn{2}{|c|}{$\begin{array}{c}\text { RWC } \\
\text { (Intensive) }\end{array}$} & \multicolumn{2}{|c|}{$\begin{array}{c}\text { RWC } \\
\text { (Moderate) }\end{array}$} \\
\hline & 25 Years & 100 Years & 25 Years & 100 Years & 25 Years & 100 Years & 25 Years & 100 Years \\
\hline Alameda & 72.9 & 35.7 & 10.6 & 5.5 & 65.5 & 40.8 & 16.5 & 12.6 \\
\hline $\begin{array}{l}\text { Contra } \\
\text { Costa }\end{array}$ & 50.4 & 23.7 & 5.1 & 4.5 & 49.6 & 29.7 & 12.3 & 8.9 \\
\hline Marin & 34.9 & 16.3 & 1.6 & -1.0 & 34.9 & 23.1 & 7.9 & 6.7 \\
\hline Napa & 42.2 & 19.4 & 6.7 & 5.6 & 40.0 & 22.2 & 11.1 & 6.9 \\
\hline $\begin{array}{c}\text { San } \\
\text { Francisco }\end{array}$ & 92.2 & 40.1 & 13.3 & 11.2 & 87.8 & 47.6 & 22.2 & 13.9 \\
\hline San Mateo & 61.9 & 29.5 & 7.5 & 3.7 & 59.0 & 35.7 & 14.9 & 10.2 \\
\hline Santa Clara & 79.5 & 37.9 & 10.7 & 4.6 & 69.8 & 42.8 & 17.8 & 13.2 \\
\hline Solano & 59.7 & 19.8 & 6.0 & -3.6 & 58.2 & 28.8 & 14.9 & 8.1 \\
\hline Sonoma & 40.0 & 23.1 & 2.2 & 2.6 & 37.8 & 28.2 & 8.9 & 7.7 \\
\hline
\end{tabular}

Tables 2 and 3 also show that all interventions provide benefits across all counties, bar small dis-benefits seen in Marin and Solano created by the moderate urban greening intervention during the 100-year flood event. This dis-benefit is associated with the aforementioned mechanism of urban greening slowing water in the upper catchment and leading to accumulation of shallow inundation depths which lead to more damage. This highlights the importance of spatial analysis over multiple return periods; however, it is noted that this effect is only seen in two counties, with all others indicating a benefit.

\section{Discussion}

\subsection{Rapid Modelling as a Component of Regional Scale Stormwater Management}

This research highlights several key advantages of rapid modelling as a component of scenario exploration. The primary novelty of the work is the ability to integrate regional scale simulation of stormwater flooding and interventions within decision support processes during the informative early stages of strategy consideration and preliminary design. This is facilitated through application of a cellular automata, run with easily accessible and open access data, representing an approach replicable by stakeholders with limited re- 
source (time and financial) for expensive licensing, processing or monitoring. The method therefore provides a useful means to engage stakeholders, explore options at the regional scale investment decisions are made and direct further actions, such as data gathering, model acquisition and strategic targeting.

The regional scale perspective of our study also responds to a growing narrative in green infrastructure research that isolated conventional solutions are not sufficient to manage the increasing demands on infrastructure created by increasing hazards and limited resources. Instead, this study highlights that catchment-scale flooding requires management through distributed, diverse and novel technologies such as green infrastructure $[5,14,17,23,84,85]$. The methodology supports analysis at the regional scale and connects the various stakeholders who can play a role in the development of aspirational landscape strategies, advancing from a historic paradigm of isolated site-based measures which do not always connect at the catchment scale [16,22,27,34].

The approach also enables a spatial consideration of benefits, integrating analysis at across regional, catchment and sub-catchment scales. This resolution provides valuable insight into spatial disaggregation of hazards and helps stakeholders to orient policy accordingly by applying spatial understanding and scenario exploration to target interventions, data gathering and engagement where the potential benefits are most required.

Integration of ecosystem services, albeit in a simplified way, provides an opportunity for decision support to identify the value of interventions at an early stage of analysis and can start to develop evidence bridging the gap between green and conventional strategies. Among the most popular regional scale ecosystem services tools (e.g., InVEST, ARIES, MIMES, i-Tree, none, to our knowledge, provide a spatially explicit assessment of flood risk with inundation maps. New approaches such as the one presented here are valuable, as they provide a quantitative and spatial estimate of inundation risk that help engage with urban planners. This is of particular importance given the risk-averse nature of regional decision making being susceptible to the inertia of 'tried and tested' solutions with a historic evidence base at the expense of implementing new technologies $[29,86]$.

Regional and rapid screening does have significant limitations which need to be acknowledged to ensure it is applied in an effective, useful and responsible manner. The most significant of these limitations is the uncertainty inherent to the rapid screening through simplifications to the DEM and parameterisations of physical processes. Representing the landscape-scale using this approach requires a relatively coarse grid scale of the underlying DEM which may not accurately represent the effects that urban micro-topographical features such as kerbs, walls, ditches and fences have on runoff flows [87-89]. Similarly, simplification of underlying physical processes through applying a set infiltration rate for each broad land use type and a lack of a full 1D pipe flow simulation means that the approach is not suitable for detailed design. However, literature highlights that detailed and high-resolution data is not always required, and that data should instead be aligned to the scope of decisions for which a model is intended [90,91]. In this case a broad regional representation of flood hazards using open source and easily accessible data is required to enable scenario exploration, data need identification and stakeholder engagement. Although it should also be noted that baseline simulations do still align with publicly available data sources [92] and liaison with regional expert stakeholders from the Bay Area, indicating that flood hotspots correlated between this rapid approach and available understanding and mapping. However, the authors do stress that this type of efficient modelling is only suitable for the initial screening of regional flood dynamics and does not fully represent the detail required for drainage design and high-resolution flood modelling.

Furthermore, the exploratory modelling here focuses on estimating the benefits of strategies and is too high level to accurately gauge the full design costs of implementing these, which would require comprehensive understanding and analysis of site-specific factors, better suited to latter stages of detailed design. It is recommended that future research further explore whether intervention installation, operation and maintenance 
costs, as well as sustainability criteria such as carbon footprints, can also be estimated at a similar exploratory scale. This understanding will likely develop as the evidence base for regional implementation of green infrastructure is advanced; However, it should be noted that existing site scale studies do already indicate that general application of urban greening and sustainable drainage retrofit is cost effective when applied to target design standard flood events [93,94].

The trade-off between data availability, cost, simulation speed and simplicity of regional design versus accuracy at the site scale means that this type of preliminary analysis should only be applied for initial regional exploratory modelling, rather than results at individual sites being used as the basis for detailed design decisions. This ensures that uncertainties regarding high-level data inputs and simplifications during the runoff simulation and cost evaluation are not over-sold to stakeholders. The place and utility of rapid regional models in the landscape planning discipline are therefore in terms of a complementary approach to existing models; to inform, co-ordinate and steer, rather than replace, existing detailed and site-specific approaches used widely across urban and landscape management.

\subsection{What Do These Results Mean for Stormwater Interventions in the Bay Area?}

The results of this study indicate that regional scale implementation of green infrastructure interventions can provide a valuable ecosystem service benefit in the context of reducing flood damages. This is particularly relevant in terms of managing design standard events, such as the 25-year flood in which intensive urban greening reduces direct economic losses by $66 \%$ over the baseline when considered across the full region. The benefit of intensive urban greening is even more pronounced in specific counties: for example, Alameda and Santa Clara, where it reduces damages by $73 \%$ and $80 \%$ relative to the baseline; and San Francisco, where this intervention realises a $92 \%$ damage reduction versus the baseline. Intensive rainwater capture also evidences a strong benefit to the region, with most effective application locations mirroring the most effective applications of urban greening, including realising up to a $88 \%$ damage reduction in San Francisco. These commonalities between where measures are most effective highlight the utility of this method for identifying priority counties to target regional scale intervention strategies across, and could be a useful tool in integrating understanding between multi-disciplinary regional stakeholders during preliminary design [26,34,38,39].

All interventions provide less benefits during extreme flooding. This supports other stormwater management literature which highlights that alternative coping mechanisms, such as resilience and recovery, are required when planning for extreme events $[8,22,25,95]$. Effectiveness of interventions also changes during the extreme event, with rainwater capture exhibiting a higher benefit in terms of damage reduction than urban greening. This is attributed to the aforementioned slowing of runoff caused by urban greening, leading to ponding. In practice it is likely that any disbenefits caused by runoff ponding can be mitigated through designing adequate storage as part of urban greening strategies; however, even with careful design, it is always possible for extreme rainfall to exceed the capacity of storage systems, regardless of whether these are based on grey or green infrastructure. As such, this finding supports use of capture-based interventions for managing design standard events and highlights the need to enhance community awareness, preparedness and resilience to extreme flood events.

Another key message from our analysis is that decentralised regional strategies are most effective when they are deployed extensively across catchments. This can be observed through the disparity between relatively low benefits for moderate application versus significantly higher benefits for intensive applications. This is most apparent in the 25-year flood event, where moderate urban greening reduces damages versus the baseline of between $1.6 \%$ and $13.3 \%$, whereas intensive urban greening reduces damages by between $34.9 \%$ and $92.2 \%$. A similar result is observed with rainwater capture, where moderate capture leads to range of $7.9 \%$ to $22.2 \%$, versus intensive capture achieving a $34.9 \%$ to 
$87.8 \%$ reduction in damages. This supports other literature highlighting that aspirational strategies implementing extensive decentralised application of green infrastructure are desirable across a catchment scale to maximise benefits and mitigate the increasing pressures of climate change and urbanisation $[22,25,27,34]$.

It is of note that benefit values are likely to be an underestimate of the actual ecosystem service afforded by the intervention due to the damage model only taking into account direct and tangible losses to the building and contents, rather than including the direct and tangible costs to stocks, critical infrastructure and other vulnerable land uses. Furthermore, the method does not encapsulate the indirect or intangible losses attributed to impacts such as cascading effects of infrastructure disruption and negative outcomes to physical and mental health $[76,96]$. The flood reduction benefit of interventions is therefore likely to be underestimated relative to these outcomes. This provides strong support for further investigating intensive application of green infrastructure distributed across these counties. Similarly, our analysis focuses on the impact of single high impact events. Strong intervention performance observed during design standard events indicates that future research should further examine the benefits of interventions in terms of mitigating impacts from the frequent smaller but cumulative events which often receive less attention.

Furthermore, our method does not encapsulate the broad range of natural capital and ecosystem service benefits that various interventions, particularly urban greening, may provide $[15,97]$. Such efforts are currently undertaken regionally, for example through the Bay Area Greenprint [98] or efforts to develop adaptation strategies to sea-level rise [99]. They are particularly crucial for green infrastructure, which are widely recognised as providing multiple services such as health benefits (mental and physical), air quality improvements, public amenity, carbon sequestration, water supply resilience and managing urban heat islands [3,30,84,100-102]. Integration of flood risk mitigation benefits into broader ecosystem services assessments will provide a wider view of regional landscape management opportunities. This is of significance when evaluating the differences between urban greening, which is likely to have significant additional ecosystem service benefits to heat reduction, biodiversity and recreation, versus rainwater capture, which is less likely to exhibit these benefits typically associated with urban green space $[3,26,29,100,103]$. However, it should be noted that recent developments to urban rainwater capture infrastructure, such as community systems, active control and smart technology enabling real time catchment management may also enhance the effectiveness and benefits of capture technology [72,102-108], and subsequent research should explore this further.

Overall, consideration of additional ecosystem services suggests that interventions have a higher economic value than presented here. Nevertheless, the study supports that significant flood risk benefits can be realised with the intensive and distributed application of green infrastructure interventions at a regional scale.

One cautionary outcome from the study indicates that the green infrastructure effectiveness declines during the extreme flood events due to interventions exceeding capacity and water ponding upstream in catchments. In fact, despite large improvements attributed to interventions, it is apparent that significant damage costs remain across all scenarios. This emphasises the need for a variety of intervention options, including measures to mitigate hazards, such as those explored here, alongside adaption and coping mechanisms to boost resilience amongst affected communities, infrastructure and services [8]. This corroborates with literature supporting that green infrastructure, or by extension any medium volume distributed intervention, does have a finite capacity and therefore an effectiveness tipping point $[25,60]$. These tipping points are crucial to identify within flood management due to the likelihood of climate change increasing the intensity of future storms, thus reducing the level of protection identified during intervention design. The implication is that resistance based interventions alone are insufficient to guard against future flood damage [8]. Instead, these strategies should be considered as one component of an inclusive urban water management strategy which includes conventional infrastructure for everyday drainage, distributed and connected catchment wide solutions for managing design storms 
and community led flood resilience measures to cope with the inevitable events which exceed the capacities of even aspirational catchment wide intervention strategies.

In terms of translating these findings into actionable guidelines, our preliminary analysis indicates a strong potential for urban greening and rainwater capture to be integrated across the San Francisco Bay Area, in particular through targeting counties of Alameda, Santa Clara and San Francisco where benefits appear particularly high. Both strategies exhibit promise for managing design standard events, but should be complemented with additional community resilience strategies to prepare for extreme flooding which exceeds intervention capacities. All strategies present significant and similar benefits, however further research is recommended to examine whether novel technology can be developed to provide additional ecosystem services.

The consistency of these findings across the spatially diverse regional study area is promising for similar approaches to be investigated across other conurbations, however we caution that this kind of exploratory regional analysis should only be applied to inform and evidence next steps in coordinating decision support and is unsuitable to replace the detailed modelling and comprehensive cost benefit analysis which should form the basis of full strategy design.

\section{Conclusions}

This research successfully implements an approach for scenario exploration early in the landscape management design process. Application of easily accessible data and rapid modelling generates a methodology which can be applied to provide baseline information on regional stormwater flood risk mitigation, in combination with existing detailed approaches. The regional perspective connects catchment scale opportunities for water management, enhancing opportunities for distributed natural flood interventions, which research supports as effective measures to reduce urban flooding.

Even though a preliminary and exploratory approach, the study highlights the potential for significant stormwater benefits from regional application of green infrastructure, with application across some counties demonstrating up to a $92 \%$ reduction in flood damages during a 25-year flood event. Despite being a high-level analysis, understanding the potential of measures at a preliminary stage in design is a useful tool to motivate and engage multi-disciplinary stakeholders towards considering opportunities for regional scale stormwater management.

This study focuses on the stormwater element of ecosystem services, it is recommended that the next step is to integrate this approach within existing ecosystem services evaluation frameworks, with the aim of developing a comprehensive initial assessment of ecosystem benefits which can inform regional landscape planning. It is also recommended that future research evaluate uncertainties associated with the rapid modeling approach and how rapid screening and detailed site-scale models can be integrated to develop effective, inclusive and informed landscape management from initial regional scale screening through to site-focused implementation.

Author Contributions: Conceptualisation, J.L.W. and P.H.; methodology, J.L.W., M.B., D.L. and P.H.; software, M.J.G.; validation and formal analysis, J.L.W., M.B. and P.H.; writing-original draft preparation, All; writing-review and editing, All; visualisation, J.L.W., M.B. and P.H.; supervision, D.B., D.L., G.F. and P.H.; funding acquisition, J.L.W., D.B., D.L., G.F. and P.H. All authors have read and agreed to the published version of the manuscript.

Funding: This research was supported by the Natural Capital Project, the UK Engineering and Physical Sciences Research Council ‘Building Resilience Into risk Management' (BRIM) network (EP/N010329/1) and the UK Natural Environment Research Council 'South West Partnership for Environment and Economic Prosperity' (SWEEP) (NE/P011217/1). Perrine Hamel and James Webber were partially funded by a grant from the Betty and Gordon Moore Foundation. Perrine Hamel and David Lallemant were funded by Nanyang Technological University and National Research Foundation, Prime Minister's Office, Singapore under awards NRF-NRFF12-2020-0009 and NRF- 
NRFF2018-06. Mariano Balbi was funded by a Peruilh Scholarship from the Engineering School at Universidad de Buenos Aires.

Institutional Review Board Statement: Not applicable.

Informed Consent Statement: Not applicable.

Data Availability Statement: Data underpinning this study is available upon reasonable request through contacting the authors.

Conflicts of Interest: The authors declare no conflict of interest.

\section{References}

1. Committee on Climate Change. UK Climate Change Risk Assessment 2017 Synthesis Report. 2017. Available online: https:/ / www.theccc.org.uk/wp-content/uploads/2016/07/UK-CCRA-2017-Synthesis-Report-Committee-on-Climate-Change.pdf (accessed on 4 July 2017).

2. Guerreiro, S.B.; Dawson, R.J.; Kilsby, C.; Lewis, E.; Ford, A. Future heat-waves, droughts and floods in 571 European cities. Environ. Res. Lett. 2018, 13, 034009. [CrossRef]

3. Norton, B.A.; Coutts, A.M.; Livesley, S.; Harris, R.J.; Hunter, A.M.; Williams, N. Planning for cooler cities: A framework to prioritise green infrastructure to mitigate high temperatures in urban landscapes. Landsc. Urban Plan. 2015, 134, 127-138. [CrossRef]

4. Carter, J.G.; White, I.; Richards, J. Sustainability appraisal and flood risk management. Environ. Impact Assess. Rev. 2009, 29, 7-14. [CrossRef]

5. Wong, T.H.F.; Brown, R.R. The water sensitive city: Principles for practice. Water Sci. Technol. 2009, 60, 673-682. [CrossRef] [PubMed]

6. Hallegatte, S.; Green, C.; Nicholls, R.; Corfee-Morlot, J. Future flood losses in major coastal cities. Nat. Clim. Chang. 2013, 3 , 802-806. [CrossRef]

7. Djordjević, S.; Butler, D.; Gourbesville, P.; Mark, O.; Pasche, E. New policies to deal with climate change and other drivers impacting on resilience to flooding in urban areas: The CORFU approach. Environ. Sci. Policy 2011, 14, 864-873. [CrossRef]

8. Butler, D.; Ward, S.; Sweetapple, C.; Imani, M.; Diao, K.; Farmani, R.; Fu, G. Reliable, resilient and sustainable water management: The Safe \& SuRe approach. Glob. Challenges 2016, 1, 63-77. [CrossRef]

9. Pitt, M. 2008 The Pitt review: Learning lessons from the 2007 floods. Available online: https:/ /webarchive.nationalarchives.gov. uk/20100812084907/http://archive.cabinetoffice.gov.uk/pittreview/_/media/assets/www.cabinetoffice.gov.uk/flooding_ review / pitt_review_full\%20pdf.pdf (accessed on 23 July 2021).

10. EWA. EWA Expert Meeting on Pluvial Flood Risk in Europe Report. 2009. Available online: http://www.dwa.de/portale/ewa/ ewa.nsf/C125723B0047EC38/B5A125AF564B24E2C1257750002C1FD9/\$FILE/EWAexpertmeetingonpluvialflood_FinalReport. pdf (accessed on 8 March 2018).

11. Löwe, R.; Urich, C.; Domingo, N.S.; Mark, O.; Deletic, A.; Arnbjerg-Nielsen, K. Assessment of urban pluvial flood risk and efficiency of adaptation options through simulations-A new generation of urban planning tools. J. Hydrol. 2017, 550, 355-367. [CrossRef]

12. Wing, O.E.J.; Bates, P.D.; Smith, A.M.; Sampson, C.C.; A Johnson, K.; Fargione, J.; Morefield, P. Estimates of present and future flood risk in the conterminous United States. Environ. Res. Lett. 2018, 13, 034023. [CrossRef]

13. Burns, M.J.; Fletcher, T.D.; Walsh, C.J.; Ladson, A.; Hatt, B.E. Hydrologic shortcomings of conventional urban stormwater management and opportunities for reform. Landsc. Urban Plan. 2012, 105, 230-240. [CrossRef]

14. Woods Ballard, B.; Wilson, S.; Udale-Clarke, H.; Illman, S.; Scott, T.; Ashley, R.; Kellagher, R. The SuDS Manual (C753); CIRIA: London, UK, 2015.

15. Fenner, R. Spatial Evaluation of Multiple Benefits to Encourage Multi-Functional Design of Sustainable Drainage in Blue-Green Cities. Water 2017, 9, 953. [CrossRef]

16. Kuller, M.; Farrelly, M.; Deletic, A.; Bach, P.M. Building effective Planning Support Systems for green urban water infrastructurePractitioners' perceptions. Environ. Sci. Policy 2018, 89, 153-162. [CrossRef]

17. Fletcher, T.D.; Shuster, W.; Hunt, W.F.; Ashley, R.; Butler, D.; Arthur, S.; Trowsdale, S.; Barraud, S.; Semadeni-Davies, A.; BertrandKrajewski, J.-L.; et al. SUDS, LID, BMPs, WSUD and more-The evolution and application of terminology surrounding urban drainage. Urban Water J. 2014, 12, 525-542. [CrossRef]

18. Jones, M.R.; Fowler, H.; Kilsby, C.; Blenkinsop, S. An assessment of changes in seasonal and annual extreme rainfall in the UK between 1961 and 2009. Int. J. Clim. 2012, 33, 1178-1194. [CrossRef]

19. Westra, S.J.; Fowler, H.; Evans, J.; Alexander, L.; Berg, P.; Johnson, F.; Kendon, E.J.; Lenderink, G.; Roberts, N.M. Future changes to the intensity and frequency of short-duration extreme rainfall. Rev. Geophys. 2014, 52, 522-555. [CrossRef]

20. Meehl, G.A.; Karl, T.; Easterling, D.R.; Changnon, S.; Pielke, R.; Changnon, D.; Evans, J.; Groisman, P.Y.; Knutson, T.R.; Kunkel, K.E.; et al. An Introduction to Trends in Extreme Weather and Climate Events: Observations, Socioeconomic Impacts, Terrestrial Ecological Impacts, and Model Projections. Bull. Am. Meteorol. Soc. 2000, 81, 413-416. [CrossRef] 
21. Quevauviller, P. Adapting to climate change: Reducing water-related risks in Europe-EU policy and research considerations. Environ. Sci. Policy 2011, 14, 722-729. [CrossRef]

22. Hoang, L.; Fenner, R. System interactions of stormwater management using sustainable urban drainage systems and green infrastructure. Urban Water J. 2015, 13, 739-758. [CrossRef]

23. Schubert, J.E.; Burns, M.J.; Fletcher, T.D.; Sanders, B.F. A framework for the case-specific assessment of Green Infrastructure in mitigating urban flood hazards. Adv. Water Resour. 2017, 108, 55-68. [CrossRef]

24. Meng, T.; Hsu, D. Stated preferences for smart green infrastructure in stormwater management. Landsc. Urban Plan. 2019, 187, 1-10. [CrossRef]

25. Webber, J.L.; Fletcher, T.D.; Cunningham, L.; Fu, G.; Butler, D.; Burns, M.J. Is green infrastructure a viable strategy for managing urban surface water flooding? Urban Water J. 2019, 17, 598-608. [CrossRef]

26. Zhang, K.; Deletic, A.; Dotto, C.B.S.; Allen, R.; Bach, P.M. Modelling a 'business case' for blue-green infrastructure: Lessons from the Water Sensitive Cities Toolkit. Blue-Green Syst. 2020, 2, 383-403. [CrossRef]

27. O'Donnell, E.; Thorne, C.; Ahilan, S.; Arthur, S.; Birkinshaw, S.; Butler, D.; Dawson, D.; Everett, G.; Fenner, R.; Glenis, V.; et al. The blue-green path to urban flood resilience. Blue-Green Syst. 2019, 2, 28-45. [CrossRef]

28. Jose, R.; Wade, R.; Jefferies, C. Smart SUDS: Recognising the multiple-benefit potential of sustainable surface water management systems. Water Sci. Technol. 2015, 71, 245-251. [CrossRef] [PubMed]

29. Mijic, A.; Ossa-Moreno, J.; Smith, K.M. Multifunctional Benefits of SuDS: Techno-Economic Evaluation of Decentralised Solutions for Urban Water Management. In Geophysical Research Abstracts EGU General Assembly; 2016; Volume 18, p. 9994. Available online: http:/ / meetingorganizer.copernicus.org/EGU2016/EGU2016-9994.pdf (accessed on 24 August 2017).

30. Keeler, B.L.; Hamel, P.; McPhearson, T.; Hamann, M.H.; Donahue, M.L.; Prado, K.A.M.; Arkema, K.K.; Bratman, G.N.; Brauman, K.A.; Finlay, J.C.; et al. Social-ecological and technological factors moderate the value of urban nature. Nat. Sustain. 2019, 2, 29-38. [CrossRef]

31. E Pataki, D.; Carreiro, M.M.; Cherrier, J.; E Grulke, N.; Jennings, V.; Pincetl, S.; Pouyat, R.V.; Whitlow, T.H.; Zipperer, W.C. Coupling biogeochemical cycles in urban environments: Ecosystem services, green solutions, and misconceptions. Front. Ecol. Environ. 2011, 9, 27-36. [CrossRef]

32. Burns, M.J.; Wallis, E.; Matic, V. Building capacity in low-impact drainage management through research collaboration. Freshw. Sci. 2015, 34, 1176-1185. [CrossRef]

33. Giese, E.; Rockler, A.; Shirmohammadi, A.; Pavao-Zuckerman, M.A. Assessing Watershed-Scale Stormwater Green Infrastructure Response to Climate Change in Clarksburg, Maryland. J. Water Resour. Plan. Manag. 2019, 145, 05019015. [CrossRef]

34. Oral, H.V.; Carvalho, P.; Gajewska, M.; Ursino, N.; Masi, F.; van Hullebusch, E.D.; Kazak, J.; Exposito, A.; Cipolletta, G.; Andersen, T.R.; et al. A review of nature-based solutions for urban water management in European circular cities: A critical assessment based on case studies and literature. Blue-Green Syst. 2020, 2, 112-136. [CrossRef]

35. Keeler, B.L.; Dalzell, B.; Gourevitch, J.D.; Hawthorne, P.; A Johnson, K.; Noe, R.R. Putting people on the map improves the prioritization of ecosystem services. Front. Ecol. Environ. 2019, 17, 151-156. [CrossRef]

36. Elliott, A.H.; Trowsdale, S.A. A review of models for low impact urban stormwater drainage. Env. Mod. Soft. 2007, 22, 394-405. [CrossRef]

37. Jayasooriya, V.M.; $\mathrm{Ng}$, A.W. Tools for modeling of stormwater management and economics of green infrastructure practices: A review. Water Air Soil Pollut. 2014, 225, 2055. [CrossRef]

38. Frantzeskaki, N. Seven lessons for planning nature-based solutions in cities. Environ. Sci. Policy 2019, 93, 101-111. [CrossRef]

39. Kabisch, N.; Frantzeskaki, N.; Pauleit, S.; Naumann, S.; Davis, M.; Artmann, M.; Haase, D.; Knapp, S.; Korn, H.; Stadler, J.; et al. Nature-based solutions to climate change mitigation and adaptation in urban areas: Perspectives on indicators, knowledge gaps, barriers, and opportunities for action. Available online: https://www.jstor.org/stable/26270403 (accessed on 16 June 2021).

40. Lechner, A.M.; Gomes, R.L.; Rodrigues, L.; Ashfold, M.J.; Selvam, S.B.; Wong, E.P.; Raymond, C.M.; Zieritz, A.; Sing, K.W.; Moug, P.; et al. Challenges and considerations of applying nature-based solutions in low- and middle-income countries in Southeast and East Asia. Blue-Green Syst. 2020, 2, 331-351. [CrossRef]

41. McKenzie, E.; Posner, S.; Tillmann, P.; Bernhardt, J.R.; Howard, K.; Rosenthal, A. Understanding the Use of Ecosystem Service Knowledge in Decision Making: Lessons from International Experiences of Spatial Planning. Environ. Plan. C Gov. Policy 2014, 32, 320-340. [CrossRef]

42. Davoudi, S. Evidence-Based Planning. disP Plan. Rev. 2006, 42, 14-24. [CrossRef]

43. Rich, R.F. Measuring knowledge utilization: Processes and outcomes. Knowl. Soc. 1997, 10, 11-24. [CrossRef]

44. Tozer, L.; Hörschelmann, K.; Anguelovski, I.; Bulkeley, H.; Lazova, Y. Whose city? Whose nature? Towards inclusive nature-based solution governance. Cities 2020, 107. [CrossRef]

45. Dottori, F.; Todini, E. Developments of a flood inundation model based on the cellular automata approach: Testing different methods to improve model performance. Phys. Chem. Earth, Parts A/B/C 2011, 36, 266-280. [CrossRef]

46. Caviedes-Voullième, D.; Fernández-Pato, J.; Hinz, C. Cellular Automata and Finite Volume solvers converge for 2D shallow flow modelling for hydrological modelling. J. Hydrol. 2018, 563, 411-417. [CrossRef]

47. Murray, A.B.; Paola, C. A cellular model of braided rivers. Nat. Cell Biol. 1994, 371, 54-57. [CrossRef]

48. Douvinet, J.; van de Wiel, M.J.; Delahaye, D.; Cossart, E. A flash flood hazard assessment in dry valleys (northern France) by cellular automata modelling. Nat. Hazards 2014, 75, 2905-2929. [CrossRef] 
49. Rinaldi, P.R.; Dalponte, D.D.; Vénere, M.J.; Clausse, A. Cellular automata algorithm for simulation of surface flows in large plains. Simul. Model. Pr. Theory 2007, 15, 315-327. [CrossRef]

50. Li, Y.; Gong, J.; Liu, H.; Zhu, J.; Song, Y.; Liang, J. Real-time flood simulations using CA model driven by dynamic observation data. Int. J. Geogr. Inf. Sci. 2015, 29, 1-13. [CrossRef]

51. Kassogué, H.; Bernoussi, A.; Maâtouk, M.; Amharref, M. A two scale cellular automaton for flow dynamics modeling (2CAFDYM). Appl. Math. Model. 2017, 43, 61-77. [CrossRef]

52. Parsons, J.A.; Fonstad, M. A cellular automata model of surface water flow. Hydrol. Process. 2007, 21, 2189-2195. [CrossRef]

53. Liu, H.; Wang, Y.; Zhang, C.; Chen, A.S.; Fu, G. Assessing real options in urban surface water flood risk management under climate change. Nat. Hazards 2018, 94, 1-18. [CrossRef]

54. Gibson, M.J.; Savic, D.A.; Djordjevic, S.; Chen, A.S.; Fraser, S.; Watson, T. Accuracy and Computational Efficiency of 2D Urban Surface Flood Modelling Based on Cellular Automata. Procedia Eng. 2016, 154, 801-810. [CrossRef]

55. Guidolin, M.; Duncan, A.; Ghimire, B.; Gibson, M.; Keedwell, E.; Chen, A.S.; Djordjević, S. CADDIES: A New Framework for Rapid Development of Parallel Cellular Automata Algorithms for Flood Simulation. 2012. Available online: https:/ / ore.exeter.ac.uk/repository/bitstream/handle/10036/3742/HIC2012_0044_CADDIES_A_new_framework_for_ rapid_development_of_parallel_cellula.pdf?sequence=2\&isAllowed=y (accessed on 10 May 2017).

56. Guidolin, M.; Chen, A.; Ghimire, B.; Keedwell, E.C.; Djordjević, S.; Savić, D.A. A weighted cellular automata 2D inundation model for rapid flood analysis. Environ. Model. Softw. 2016, 84, 378-394. [CrossRef]

57. Ghimire, B.; Chen, A.S.; Guidolin, M.; Keedwell, E.C.; Djordjevic, S.; Savic, D. Formulation of a fast 2D urban pluvial flood model using a cellular automata approach. J. Hydroinformatics 2012, 15, 676-686. [CrossRef]

58. Webber, J.; Booth, G.; Gunasekara, R.; Fu, G.; Butler, D. Validating a rapid assessment framework for screening surface water flood risk. Water Environ. J. 2018, 33, 427-442. [CrossRef]

59. Wang, Y.; Chen, A.; Fu, G.; Djordjevic, S.; Zhang, C.; Savić, D.A. An integrated framework for high-resolution urban flood modelling considering multiple information sources and urban features. Environ. Model. Softw. 2018, 107, 85-95. [CrossRef]

60. Webber, J.L.; Fu, G.; Butler, D. Comparing cost-effectiveness of surface water flood management interventions in a UK catchment. J. Flood Risk Manag. 2019, 12. [CrossRef]

61. Bayareacensus.ca.gov. Bay Area Census 2010. 2010. Available online: http://www.bayareacensus.ca.gov (accessed on 11 December 2019).

62. USGS. National Elevation Dataset. 2019. Available online: https://catalog.data.gov/dataset/usgs-national-elevation-dataset-ned (accessed on 11 December 2019).

63. NOAA. C-CAP Land Cover Atlas. 2010. Available online: http://www.csc.noaa.gov/landcover (accessed on 11 December 2019).

64. NOAA. NOAA Atlas Data-Set. 2017. Available online: https://hdsc.nws.noaa.gov/hdsc/pfds/pfds_map_cont.html (accessed on 11 December 2019).

65. Phillips, J.V.; Tadayon, S. Selection of Manning's Roughness Coefficient for Natural and Constructed Vegetated and Non-Vegetated Channels, and Vegetation Maintenance Plan Guidelines for Vegetated Channels in Central Arizona; USGS Scientific Investigations Report 2006-5108; USGS Geological Survey: Reston, VA, USA, 2006.

66. Arcement, G.J., Jr.; Schneider, V.R. Guide for Selecting Manning's Roughness Coefficients for Natural Channels and Flood Plains; Report No. FHWA-TS-84-204.; U.S. G.P.O.: Washington, DC, USA, 1989.

67. Chow, V.T. Open Channel Hydraulics; McGraw-Hill: New York, NY, USA, 1959.

68. Thomsen, B.W.; Hjalmarson, H.W. Estimated Manning's roughness coefficients for stream channels and flood plains in Maricopa County, Arizona. 1991. Available online: https:/ /www.sciencebase.gov/catalog/item/5057a17ae4b01ad7e0286f64 (accessed on 23 July 2021).

69. Butler, D.; Digman, C.; Makropoulos, C.; Davies, J. Urban Drainage, 4th ed.; CRC Press: London, UK, 2018.

70. USDA. National Engineering Handbook, Part 630 Hydrology; Chapter 7 Hydrologic Soil Group; United States Department of Agriculture: Washington, DC, USA, 2009.

71. Environment Agency. What is the Updated Flood Map for Surface Water? 2013. Available online: https://www.gov.uk/ government/uploads/system/uploads/attachment_data/file/297432/LIT_8988_0bf634.pdf (accessed on 27 January 2017).

72. Melville-Shreeve, P.; Ward, S.; Butler, D. Rainwater Harvesting Typologies for UK Houses: A Multi Criteria Analysis of System Configurations. Water 2016, 8, 129. [CrossRef]

73. Ahilan, S.; Webber, J.; Butler, D. Building urban flood resilience with rainwater management. In Proceedings of the 17th International Computing \& Control for the Water Industry Conference, Exeter, UK, 1-4 September 2019; pp. 3-4.

74. Balbi, M.; Lallemant, D. OpenProFIA. GitLab. 2017. Available online: https://gitlab.com/mbalbi/OpenPROFIA.git (accessed on 23 July 2021).

75. Jha, A.K.; Bloch, R.; Lamond, J. Cities and Flooding: A Guide to Integrated Urban Flood Risk Management for the 21st Century. World Bank. 2012. Available online: https:/ / openknowledge.worldbank.org/handle/10986/2241 (accessed on 11 December 2019).

76. Hammond, M.; Chen, A.; Djordjević, S.; Butler, D.; Mark, O. Urban flood impact assessment: A state-of-the-art review. Urban Water J. 2015, 12, 14-29. [CrossRef] 
77. University of Exeter. Flood Damage Model Guidelines. CORFU project (WP3 output). 2014. Available online: https: / / ore.exeter.ac.uk/repository/bitstream/handle/10871/21213/Flood\%20Damage\%20Model\%20Guidelines.pdf?sequence=1\& isAllowed =y (accessed on 4 July 2018).

78. FEMA Mitigation Division. Ulti-Hazard Loss Estimation Methodology, Flood Model, HAZUS, Technical Manual. 2015. Available online: https:/ / www.fema.gov/sites /default/files/2020-09/fema_hazus_flood-model_technical-manual_2.1.pdf (accessed on 23 July 2021).

79. Scawthorn, C.; Flores, P.; Blais, N.; Seligson, H.; Tate, E.; Chang, S.; Mifflin, E.; Thomas, W.; Murphy, J.; Jones, C.; et al. HAZUS-MH Flood Loss Estimation Methodology. II. Damage and Loss Assessment. Nat. Hazards Rev. 2006, 7, 72-81. [CrossRef]

80. US Army Corps of Engineers. Business Depth-Damage Analysis Procedures; US Army Corps of Engineers, Engineer Institute for Water Resources: Washington, DC, USA, 1985.

81. US Army Corps of Engineers. Catalog of Residential Depth-Damage Functions; US Army Corps of Engineers, Engineer Institute for Water Resources: Washington, DC, USA, 1992.

82. Bowker, P.; Escarameia, M.; Tagg, A. Improving the Flood Performance of New Buildings-Flood Resilient Construction; 2007 ; p. 100. Available online: https://assets.publishing.service.gov.uk/government/uploads/system/uploads/attachment_data/file/77 30/flood_performance.pdf (accessed on 27 January 2017).

83. Gölz, S.; Schinke, R.; Naumann, T. Assessing the effects of flood resilience technologies on building scale. Urban Water J. 2015, 12, 30-43. [CrossRef]

84. Kunapo, J.; Fletcher, T.D.; Ladson, A.R.; Cunningham, L.; Burns, M.J. A spatially explicit framework for climate adaptation. Urban Water J. 2018, 15, 159-166. [CrossRef]

85. Burns, M.J.; Schubert, J.E.; Fletcher, T.D.; Sanders, B.F. Testing the impact of at-source stormwater management on urban flooding through a coupling of network and overland flow models. Wiley Interdiscip. Rev. Water 2015, 2, 291-300. [CrossRef]

86. O'Donnell, E.C.; Lamond, J.E.; Thorne, C.R. Recognising barriers to implementation of Blue-Green Infrastructure: A Newcastle case study. Urban Water J. 2017, 14, 964-971. [CrossRef]

87. Fewtrell, T.J.; Duncan, A.; Sampson, C.; Neal, J.; Bates, P. Benchmarking urban flood models of varying complexity and scale using high resolution terrestrial LiDAR data. Phys. Chem. Earth Parts A/B/C 2011, 36, 281-291. [CrossRef]

88. Yu, D.; Lane, S.N. Urban fluvial flood modelling using a two-dimensional diffusion-wave treatment, part 1: Mesh resolution effects. Hydrol. Process. 2005, 20, 1541-1565. [CrossRef]

89. Mignot, E.; Paquier, A.; Haider, S. Modeling floods in a dense urban area using 2D shallow water equations. J. Hydrol. 2006, 327, 186-199. [CrossRef]

90. Box, G. Science and statistics. J. Am. Stat. Assoc. 1976, 71, 791-799. [CrossRef]

91. Dottori, F.; Di Baldassarre, G.; Todini, E. Detailed data is welcome, but with a pinch of salt: Accuracy, precision, and uncertainty in flood inundation modeling. Water Resour. Res. 2013, 49, 6079-6085. [CrossRef]

92. San Francisco Public Utilities Commission. 100-Year Storm Flood Risk Map. 2018. Available online: https://sfwater.org/index aspx?page=1229 (accessed on 11 December 2019).

93. Environment Agency. Cost estimation for SUDS-Summary of evidence (Report SC080039/R9). 2015. Available online: www.environment-agency.gov.uk (accessed on 30 January 2017).

94. Bowker, P. Flood Resistance and Resilience Solutions: An R \& D Scoping Study. 2007. Available online: https:/ /aquobex.com/ wp-content/uploads/2020/06/Flood-resilience-RD-Scoping-Study-1.pdf (accessed on 13 January 2016).

95. López-Marrero, T.; Tschakert, P. From theory to practice: Building more resilient communities in flood-prone areas. Environ. Urban. 2011, 23, 229-249. [CrossRef]

96. Labaka, L.; Hernantes, J.; Sarriegi, J.M. A holistic framework for building critical infrastructure resilience. Technol. Forecast. Soc. Chang. 2016, 103, 21-33. [CrossRef]

97. Ossa-Moreno, J.; Smith, K.M.; Mijic, A. Economic analysis of wider benefits to facilitate SuDS uptake in London, UK. Sustain. Cities Soc. 2017, 28, 411-419. [CrossRef]

98. GreenInfo Network. Bay Area Greenprint. 2021. Available online: https:/ / www.bayareagreenprint.org/ (accessed on 16 June 2021).

99. Adapting to Rising Tides. Adapting to Rising Tides Bay Area: Regional Sea Level Rise Vulnerability and Adaptation Study. 2020. Available online: http:/ / www.adaptingtorisingtides.org/project/art-bay-area / (accessed on 16 June 2016).

100. CIRIA. BeST (Benefits of SuDS Tool) W045d BeST-User Manual Release Version 1; 2015; pp. 1-22. Available online: http:// observatoriaigua.uib.es/repositori/suds_herramientas_6.pdf (accessed on 13 January 2016).

101. Bowen, K.; Lynch, Y. The public health benefits of green infrastructure: The potential of economic framing for enhanced decision-making. Curr. Opin. Environ. Sustain. 2017, 25, 90-95. [CrossRef]

102. Gómez-Baggethun, E.; Economics, D.B.-E. Classifying and Valuing Ecosystem Services for Urban Planning; 2013; pp. 235-245. Available online: https:/ / www.sciencedirect.com/science/article/pii/S092180091200362X (accessed on 11 December 2019).

103. Kuller, M.; Bach, P.M.; Roberts, S.; Browne, D.; Deletic, A. A planning-support tool for spatial suitability assessment of green urban stormwater infrastructure. Sci. Total. Environ. 2019, 686, 856-868. [CrossRef] [PubMed]

104. Campisano, A.; Butler, D.; Ward, S.; Burns, M.J.; Friedler, E.; DeBusk, K.; Fisher-Jeffes, L.N.; Ghisi, E.; Rahman, A.; Furumai, H.; et al. Urban rainwater harvesting systems: Research, implementation and future perspectives. Water Res. 2017, 115, 195-209. [CrossRef] [PubMed] 
105. Bartos, M.D.; Wong, B.; Kerkez, B. Open storm: A complete framework for sensing and control of urban watersheds. Environ. Sci. Water Res. Technol. 2017, 4, 346-358. [CrossRef]

106. Xu, W.D.; Fletcher, T.D.; Duncan, H.P.; Bergmann, D.J.; Breman, J.; Burns, M.J. Improving the Multi-Objective Performance of Rainwater Harvesting Systems Using Real-Time Control Technology. Water 2018, 10, 147. [CrossRef]

107. Xu, W.D.; Burns, M.J.; Cherqui, F.; Fletcher, T.D. Enhancing stormwater control measures using real-time control technology: A review. Urban Water J. 2020, 18, 101-114. [CrossRef]

108. Xu, W.D.; Fletcher, T.D.; Burns, M.J.; Cherqui, F. Real-Time Control of Rainwater Harvesting Systems: The Benefits of Increasing Rainfall Forecast Window. Water Resour. Res. 2020, 56. [CrossRef] 